A peer-reviewed scholarly journal

Editor: Gene V Glass

College of Education

Arizona State University

Copyright is retained by the first or sole author, who grants right of first publication to the EDUCATION POLICY ANALYSIS ARCHIVES. EPAA is a project of the Education Policy Studies Laboratory.

Articles appearing in EPAA are abstracted in the Current Index to Journals in Education by the ERIC Clearinghouse on Assessment and Evaluation and are permanently archived in Resources in Education.

\title{
What Predicts the Mobility of Elementary School Leaders? An Analysis of Longitudinal Data in Colorado
}

\author{
Motoko Akiba \\ University of Missouri-Columbia \\ Robert Reichardt
Alliance for Quality Teaching \\ Denver, Colorado
}

Citation: Akiba, M., Reichardt, R., (2004, April 24). What Predicts the Mobility of Elementary School Leaders? An Analysis of Longitudinal Data in Colorado. Education Policy Analysis Archives, 12(18). Retrieved [Date] from http://epaa.asu.edu/epaa/v12n18/.

\section{Abstract}

While many studies have reported the predictors of teacher attrition, we know little about what predicts the attrition of school leaders. Using the Colorado state data on elementary school principals' and assistant principals' career paths from 1999 to 2001 and school achievement-level data, we addressed two research questions: 1) How do the age-specific attrition rates differ by gender and race? and 2) What other conditional factors are associated with the attrition of school leaders? We found that female and minority groups generally had higher attrition rates at age 40 or younger and at age 56 or older than male and non-minority groups. Our data also indicated that school size and 
salary increase were associated with the attrition of both male and female leaders. Large schools were more likely to have higher rates of school leader attrition, and the leaders who expected relatively higher salary increases by transferring were more likely to leave their schools. Lower school achievement predicted higher attrition of female leaders only. These findings have important implications for policy-makers when they plan and implement strategies for preventing high attrition rates of school leaders.

\section{Introduction}

Recent reports and statistics have shown that many schools and districts are experiencing high attrition rates of school principals and superintendents (Cunningham \& Burdick, 1999; National Association of Elementary School Principals, 1998; U.S. Bureau of Labor Statistics, 2002). In the time of systemic educational reform, stable leadership is crucial in order for the leaders to effectively provide a rich environment for improving student learning (Useem, Christman, Gold, \& Simon, 1996). Given the empirical evidence on the important role of principal leadership to improve students' academic performance, particularly of low achievers (Andrews \& Soder, 1987; Leithwood \& Montgomery, 1982; Zigarelli, 1996), frequent turnover of school leaders would pose a serious challenge for implementing systemic educational reform.

Despite such possible negative consequences, we know little about what explains school leaders' attrition. While it has been argued that school leader attrition is caused by retirement of the baby boomer generation and those who leave education-related positions, studies have found that most attrition of educators is due to their transferring from one school to another (Ingersoll, 2001; U.S. Bureau of Labor Statistics, 2002). The increasing pressure under current educational reform to improve student achievement using the accountability system has been discussed as an important factor that discourages qualified candidates from taking leadership positions (Adams, 1999; Cooley \& Shen, 2000; Copland, 2001). Naturally, such pressures on school leaders would encourage those who are serving challenging schools to move to other schools if given the chance.

In this study, we utilized the Colorado Department of Education data on elementary school principals' and assistant principals' career paths from 1999 to 2001, which include the information on their backgrounds, working conditions and state standard-based test scores in reading and writing for fourth-graders on the Colorado State Assessment Program (CSAP) from 1999 to 2002. The research questions we addressed are: 1) How do the age-specific attrition rates differ by gender and race? and 2) What other conditional factors are associated with the attrition of school leaders?

This study represents the first attempt to empirically examine the factors associated with school leaders' attrition. The factors associated with educators' transferring have often been investigated by economists who applied labor market theory (Hanushek, Kain, \& Rivkin, 2001). In this study, we address this important policy question based on the analytical models developed from labor 
market theory. In the following sections, we will identify what the past studies have found about the major predictors of educators' attrition.

\section{Related Literature}

\section{Attrition Due to Moving and Leaving the Profession}

Most researchers have focused on attrition due to the departure of educators pursuing other noneducational jobs or retirement, or "leavers" (Bobbitt, Leich, Whitener, \& Synch, 1994; Chapman \& Hutcheson, 1982; Greenberg \& McCall, 1974; Hafner \& Owings, 1991; Haggstrom, Darling-Hammond, \& Grissmer, 1988; Heyns, 1988; Miech \& Elder, 1996; Murnane, 1987; Murnane, Singer, \& Willett, 1988; Rumberger, 1987; Schlecty \& Vance, 1981, 1983). However, attrition can be also understood as the mobility of teachers and school administrators who leave their positions to assume other teaching or administrative positions in the same district or other districts, or "movers" (Boe, Bobbitt, Cook, Barkenic, \& Maislin, 1998; Grissmer \& Kirby, 1987, 1992; Hanushek et al., 2001; Ingersoll, 2001; Murnane, 1981; Rollefson \& Broughman, 1995).

Researchers have placed less emphasis on this aspect of attrition because it does not affect the overall shortage of educators, unlike leavers. Nevertheless, studies have found that most attrition of educators is due to their moving from one school to another (Ingersoll, 2001; U.S. Bureau of Labor Statistics, 2002). In addition, from the perspective of school effectiveness, it is important to consider the attrition rates of educators regardless of whether they quit their jobs or moved to other schools. High rates of attrition at a school level mean employment instability, which affects the productivity of the organizational functions.

\section{Predictors of School Leaders' Attrition}

The only study that examined the factors influencing the leadership mobility was conducted by Ehrenberg, Chaykowski, and Ehrenberg (1988). Using the 1978-83 panel data from more than 700 New York State superintendents and their districts, they tested the hypothesis that a district's high educational performance and low school-tax rates, as the indicators of its success, were associated with superintendents' mobility to a high-paying position elsewhere. The data suggested that low school-tax rates but not achievement were significantly associated with their mobility. There have been no studies that examined the factors associated with the turnover of school leaders: principals and assistant principals.

Economic theory argues that individuals find work by choosing among alternative employment opportunities instead of attempting to maximize their own abilities. When applied to school leaders this suggests that the decision of whether to remain at a school or move to another principal position or occupation is a function of the working conditions at that school and of other opportunities. The other opportunities include other school leadership positions, other positions within the education system, and positions outside of the 
education system. Alternative opportunities for employment will vary depending upon regional labor markets (Murnane \& Olsen, 1989, 1990). The attractiveness of any given job is partially a function of individual taste and partially a function of individual factors such as age and gender, and investments in a given career, such as education.

\section{Predictors of Teacher Attrition}

While no study exists that has investigated the predictors of school leader attrition, the cumulative findings on the predictors of teacher attrition over the past two decades would provide insight. The studies on teacher attrition have found that a teacher's demographic and professional characteristics (age, gender, ethnicity, subject area, and performance level); working conditions (student characteristics, class size, existence of teacher union, district expenditures, and school decision-making system); and alternative opportunities (trajectory toward promotion, salary) are significantly associated with their decision to move or leave.

The relationship between age and teacher attrition has been found to form a U-shaped curve-younger teachers have high rates of attrition, but the rates decline through the mid-career period, yet increase again as teachers approach retirement age (Bobbitt et al., 1994; Boe et al., 1998; Grissmer \& Kirby, 1987, 1992, 1997; Hafner \& Owings, 1991; Murnane et al., 1988; Murnane, Singer, Willett, Kemple, \& Olsen, 1991). Higher attrition rates are especially distinct among young women who are most likely to leave their teaching jobs to engage in full-time child rearing. They are more likely than older women and men of all ages to leave teaching for a period of time and then return to the classroom (Murnane, 1987; Murnane \& Olsen, 1989, 1990; Murnane et al., 1988; Murnane et al., 1991).

In addition, special-education teachers and teachers whose specialty is in science (especially chemistry and physics) and mathematics are more likely to produce high rates of turnover (Bobbitt, Leich, \& Cook, 1997; Grissmer \& Kirby, 1987, 1992; Murnane, 1987; Murnane \& Olsen, 1989, 1990; Murnane et al., 1988; Murnane et al., 1991). Higher scores on the National Teacher Examination (NTE) is another factor associated with a greater likelihood of leaving a teaching job. Murnane, Singer, and Willett (1989) found that white teachers with high NTE scores are more likely to leave teaching after only a few years and are less likely to return than are white teachers with low NTE scores.

Teachers' working conditions, measured by student, school, and district characteristics, are other major factors that predict teacher turnover. Based on the data on Texas teachers, Hanuschek, Kain, and Rivken $(1999,2001)$ found that student characteristics are more important predictors of teacher turnover than salaries. Except for African American teachers, the typical Texan teacher appears to favor high-achieving, non-minority students. African American teachers also favor high-achieving students but systematically move toward schools with higher concentrations of black students (see also Carroll, Reichardt, \& Guarino, 2000; Greenberg \& McCall, 1974; Theobald, 1990).

Examining the effects of class-size characteristics on teacher turnover rates, 
Mont and Rees (1996) found that larger class size, larger number of classes taught, and the higher percentage of class time spent in areas outside a teacher's certification area were significantly associated with the higher turnover rates of high school teachers. Ingersoll (2001) found that teachers are more likely to leave their schools with the negative working conditions that include excessive class size, lack of administrative support, and a low level of teacher decision-making. Less district expenditures on instructional staff and low district salaries (Theobald \& Gritz, 1996) and the presence of teacher unions (Eberts, 1987; Rees, 1991) are other predictors of a teacher's decision to leave his or her school district.

Finally, researchers have found that the indicators of later career opportunities are also important predictors of teacher turnover. Based on the data on New York State teachers, Brewer (1996) found that male teachers are sensitive to both the availability of administrative posts and expected administrative rewards when making decisions to quit (see also Murnane et al., 1988, 1989). Higher salaries are also associated with greater retention of teachers (Baugh \& Stone, 1982; Murnane \& Olsen, 1989, 1990; Murnane et al., 1989; Murnane et al., 1991; Rumberger, 1987; Schlecty \& Vance, 1981, 1983; Theobald \& Gritz, 1996); the teachers earning more tend to stay in teaching longer than those earning less. The effect of increased salaries from old job to new job is especially significant factor for beginning teachers to leave their schools (Murnane et al., 1991).

\section{Leadership Attrition and School Achievement}

The increasing pressure in current educational reform to improve school achievement under accountability systems has been discussed as an important factor that discourages educators' pursuit of leadership positions (Cooley \& Shen, 2000; Copland, 2001). In addition, accountability systems may also discourage school leaders from applying for positions at low-achieving schools because of the intensive responsibility and potential risk associated with the difficulty of making progress in student achievement.

However, little evidence is available to explain the relationship between current accountability systems and school leaders' attrition. While we do not have any data on the indicators of accountability systems, this study will provide important information on the association between school achievement and leader turnover, which later studies on the effects of accountability systems can build upon. If we find that more leaders are moving out of low-achieving schools than high-achieving schools, two explanations are possible: 1) School leaders feel that the responsibility produced by the accountability system is excessive and are deciding to move to other schools and/or 2) the district replaced the school leader with another leader as a result of school restructuring. Our data are unable to verify either of the explanations, but the information on the association between leader attrition and school achievement level would guide future studies that have data on accountability systems.

\section{Methods}




\section{Data}

The data were collected from the Colorado Department of Education (CDE). The data include the information on all educators who have been employed by Colorado school districts from 1999 to 2001 . By merging the data from each year, we can identify the career path of educators over the three years, including leaving education-related positions, and transferring from one school to another. We selected the data on principals and assistant principals in elementary schools only. Note 1 The data comprise information on 714 principals and assistant principals in 694 elementary schools in 94 districts. Note 2 Of the school leaders in the sample, 64 percent of them were female and 19 percent were of an ethnic minority (African-American, Hispanic, Native American, or Asian). The mean age was 48.

\section{Analysis}

We conducted two sets of analyses in order to address each of our research questions. To examine our first questions on the age group-specific attrition rates by gender and race, we compared the attrition rates of male, female, minority, and non-minority school leaders by seven age categories: 35 or younger, 36 to 40 years old, 41 to 45 years old, 46 to 50 years old, 51 to 55 years old, 56 to 60 years old, and 61 or older.

In order to address our second question, the predictors of school leader attrition, we used multiple logistic regression analysis with the dependent variable of whether the school leader left to take another education-related position between 2000 and 2001. Based on the past research on teacher attrition, we included the indicators of school leaders' demographic and professional characteristics; working conditions; and alternative opportunities and the labor market as the predictors of school leader turnover. We have also included school achievement level as a predictor.

\section{Variables}

The variables used in the second sets of analyses are summarized in the following.

\section{Dependent variable}

- Movement: dichotomous variable of whether the leaders moved from their schools to other schools within or outside their school districts $(1=y e s, 0$ $=$ no).

\section{Independent variables}

- Leaders' demographic and professional characteristics:

- Minority: the minority status of the leader. African-American, Hispanic, and Native American leaders were coded as 1, the others as 0 .

- Age: dummy variables of the age group of 35 or younger and the 
age group of 51 or older, with the age group between 35 and 51 as the reference variable. Seven percent were 35 or younger, and 42 percent were 51 or older.

- Education level: dummy variables of master's degree (or specialist degree) and doctorate degree, with bachelor's degree as the reference variable. Eighty-four percent possessed a master's degree or specialist degree, and 9 percent possessed a doctorate.

- Working conditions:

- Poverty level: percentages of students receiving a free or reduced lunch program. They varied from 0 percent to 95 percent, with a mean of 33 percent.

- Percentage of minority students: the percentages of African-American, Hispanic, and Native American students. They varied from 1 percent to 99 percent, with a mean of 33 percent.

- Interaction of poverty and minority: interaction term of poverty level and percentage of minority was included because of the strong correlation between these variables.

- School size: dummy variables of large schools (i.e., 600 or more students) and small schools (400 or fewer students), with the middle-size schools, between 400 and 600 , as the reference variable. Twenty-eight percent were coded as large schools, and 31 percent were coded as small schools.

- School location: Note 3 Dummy variables of city and rural schools, with the suburban school as the reference variable. Thirty-four percent of schools were coded as city, and 22 percent of schools were coded as rural.

- School achievement level Note 4: the average percentages of fourth-graders who achieved at or above proficient level in standardized reading and writing tests in 1999, 2000, and 2001 in the schools where the leaders worked in 2000.

- Instructional expenditure per student: the district's instructional expenditure per student. The expenditures varied from $\$ 3,166$ to $\$ 6,168$, with a mean of $\$ 4,064$.

- Administrative expenditure per student: the district's administrative expenditure per students. The expenditures varied from $\$ 347$ to $\$ 1,867$, with a mean of $\$ 540$.

- Alternative opportunities and labor market:

- Annual salary difference between 2000 and 2001: the salary change in units of $\$ 1,000$ from old to new position for those who moved to another school; and the salary change based on the same job for those who stayed in the same school. The change varied from -28 to 35 , with a mean of 5 .

- Number of administrative positions: the number of principals and assistant principals within the district where the leaders moved to in 2001.

- Five Colorado labor markets: four dummy variables (the regions North, West, South, and Metro), with Pikes Peak as the reference region.

\section{Results}


Before we move to the results from the analyses that addressed our two research questions, we will note that we also examined what types of career paths constitute the rates of school leader attrition at a given school level. Figure 1 shows that the percentage of principals and assistant principals who left their schools between 1999 and 2000 and between 2000 and 2001. Three different types of career paths are presented here: 1 ) those who left education-related jobs or moved to other states, 2) those who moved to schools in other districts, and 3) those who moved to schools in the same district.

Figure 1. Attrition of School Leaders: Percentage of principals and assistant principals who left their schools during 1999-2001

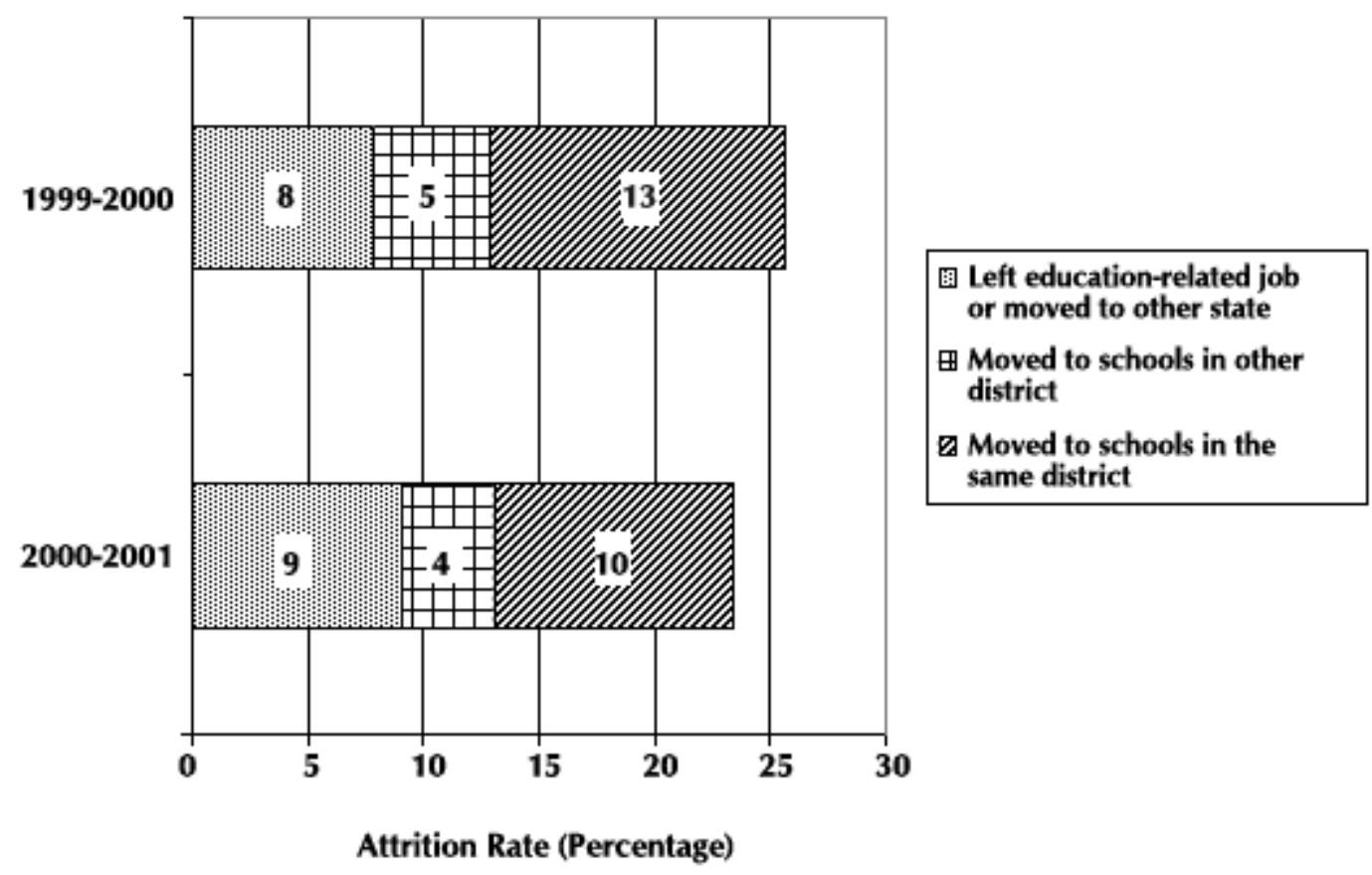

Approximately 26 percent and 23 percent of elementary school principals and assistant principals quit their schools between 1999 and 2000 and between 2000 and 2001, respectively. For the 1999-2000 data, 8 percent left their education jobs or moved to other states, 5 percent moved to schools in other districts, and 13 percent moved to schools in the same district. Between 2000 and 2001, 9 percent left their education jobs or moved to other states, 4 percent moved to schools in other districts, and 10 percent moved to schools in the same district.

A common belief regarding the turnover of school leaders is that it is explained mainly by the retirement of the baby boomer generation. However, this graph shows that the percentage of those who left (which includes those who retired) does not explain most of the school leader attrition. Indeed, only 6 percent of those who left their education job or moved to other states were age 60 or older in 1999, and only 11 percent of the population were in this age group in 2000. Therefore, contrary to conventional wisdom, the major part of school attrition is explained not by retirement but by those who move to other schools. 
Figure 2: Attrition Rate of School Leaders by Gender and Minority Status

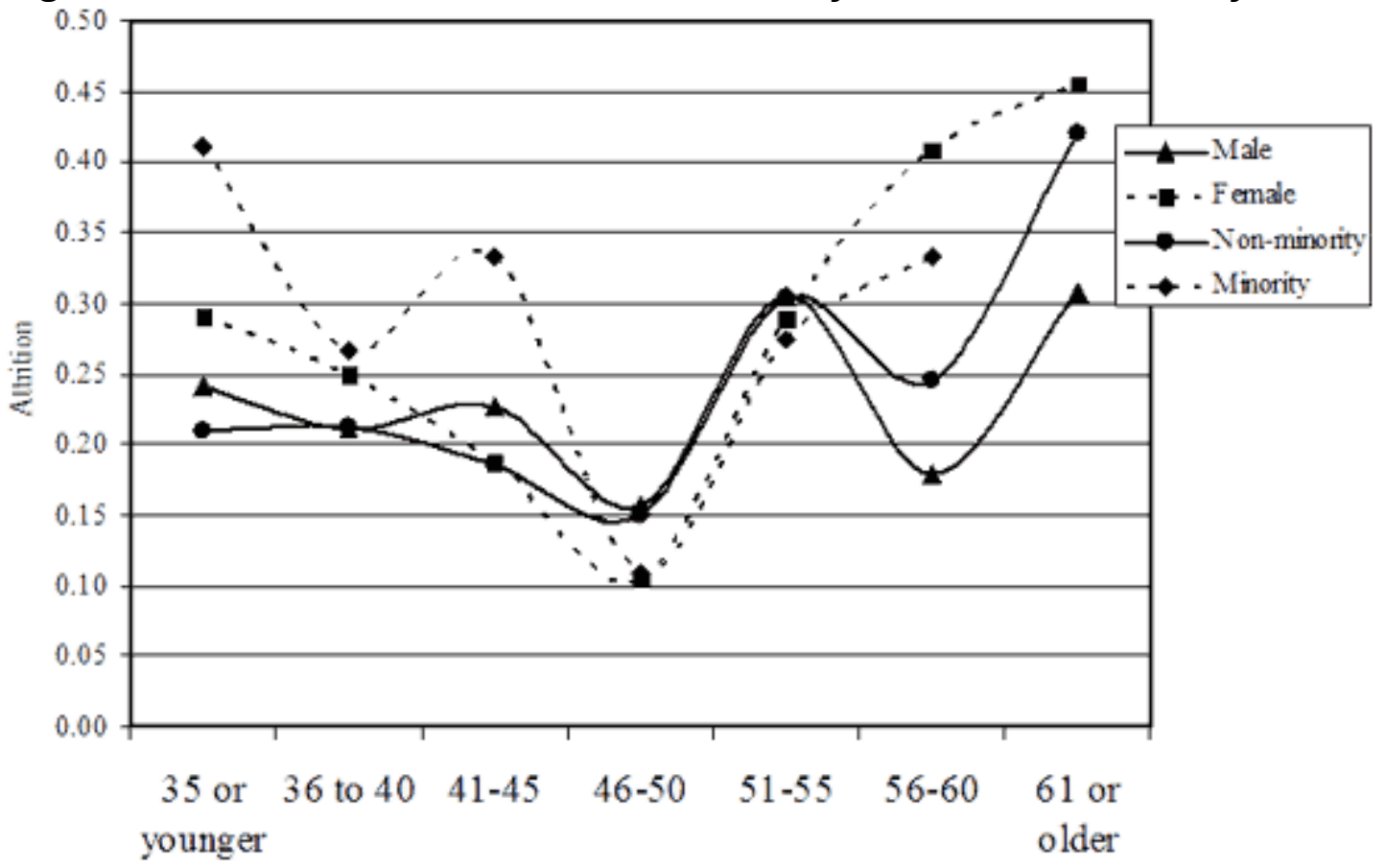

Note: The attrition rate of minority leaders who are at 61 or older is not available due to the small sample size $(\mathrm{N}=5)$.

\section{Analysis 1: The age-specific attrition rates by gender and race}

Figure 2 shows through seven age categories the percentage of principals and assistant principals who left their schools between 2000 and 2001: 35 or younger, 36 to 40 years old, 41 to 45 years old, 46 to 50 years old, 51 to 55 years old, 56 to 60 years old, and 61 or older. The four lines indicate the separate attrition rates of female, male, minority, and non-minority leaders. We can see the general patterns of U-curved attrition rates, with 35-or-younger and 61-or-older categories being the highest. However, we can see differences between female and male, and non-minority and minority groups. The attrition rates of female leaders and minority leaders are generally higher than those of male leaders and non-minority leaders, except at middle-age stages between 46 and 55.

Female and minority leaders especially have higher attrition rates at age 35 or younger (about 30 percent and 40 percent) than male ( 25 percent) and minority leaders (20 percent). Likewise, at age 56 to 60, female and minority have higher attrition rates (about 40 percent and 35 percent) than male (about 18 percent) and non-minority (25 percent). Higher female attrition rate is probably associated with the fact that younger females are more likely to leave their positions due to child rearing. However, due to the lack of past studies, we do not know what factors explain the distinctively higher attrition rate of the minority group compared to that of the non-minority groups. Future studies explaining such differences are needed. Higher attrition rates of female and minority leaders at age 56 or older than of male and non-minority leaders in that age group indicate that female and minority leaders are more likely to retire earlier 
than their counterparts. Female leaders and minority leaders may be more oriented toward their families and less inclined to prolonged professional careers after retirement age.

\section{Analysis 2: What predicts the school leader attrition?}

Given the different rates of school leader attrition, it is important to understand what factors predict principals' and assistant principals' decisions to leave their schools. From Figure 1, we can see that the major part of the school leader attrition is explained by those who moved to other schools within or outside their districts. Therefore, we excluded these leavers, whose major reasons for leaving may be different from those who moved to other schools. Figure 2 shows that there is a gender difference in the attrition rates of school leaders. Based on the possible differences between gender on the predictors of school leaders' moves, we analyzed the predictors of school leader movement separately for females and males.

The results of multiple logistic regression analysis of the predictors of school leader turnover during 2000 and 2001 are presented in Table 1. As we can see, none of the indicators of leaders' demographic and professional characteristics were significantly associated with either female or male leaders' movements except a master's/specialist degree for female leaders. Female leaders who hold a master's degree or a specialist's degree were less likely to move to other schools than those holding only a bachelor's degree.

Table 1

Predictors of Principal/Assistant Principal Turnover by Gender

\begin{tabular}{|l|l|c|c|}
\hline \multicolumn{2}{|c|}{} & Female & \multicolumn{1}{c|}{ Male } \\
\hline Sample Size & & 465 & \multicolumn{1}{c|}{260} \\
\hline Leaders' demographic and & Minority & $-.093^{\mathrm{a}}$ & .185 \\
\hline
\end{tabular}




\begin{tabular}{|c|c|c|c|}
\hline \multirow[t]{9}{*}{ Working Conditions } & Poverty & $\begin{array}{r}-.033 \\
(.024)\end{array}$ & $\begin{array}{r}.032 \\
(.033)\end{array}$ \\
\hline & Minority (Students) & $\begin{array}{r}-.012 \\
(.022)\end{array}$ & $\begin{array}{l}-.009 \\
(.040)\end{array}$ \\
\hline & Poverty X Minority ${ }^{C}$ & $\begin{array}{r}.001 \\
(.000)\end{array}$ & $\begin{array}{l}-.001 \\
(.001)\end{array}$ \\
\hline & Large School & $\begin{array}{r}.924 \\
(.313)^{\star *}\end{array}$ & $\begin{array}{r}.794 \\
(.478)^{\dagger}\end{array}$ \\
\hline & Small School & $\begin{array}{r}-.485 \\
(.861)\end{array}$ & $\begin{array}{r}.347 \\
(1.024)\end{array}$ \\
\hline & City & $\begin{array}{r}-.060 \\
(.439)\end{array}$ & $\begin{array}{r}.941 \\
(.602)\end{array}$ \\
\hline & Rural & $\begin{array}{r}.142 \\
(.453)\end{array}$ & $\begin{array}{l}.068 \\
(.662)\end{array}$ \\
\hline & $\begin{array}{l}\text { Instructional } \\
\text { expenditure per } \\
\text { student }\end{array}$ & $\begin{array}{r}.001 \\
(.001)\end{array}$ & $\begin{array}{r}.000 \\
(.001)\end{array}$ \\
\hline & $\begin{array}{l}\text { Administrative support } \\
\text { per student }\end{array}$ & $\begin{array}{r}.002 \\
(.001)\end{array}$ & $\begin{array}{l}-.002 \\
(.002)\end{array}$ \\
\hline \multirow[t]{3}{*}{ School Achievement } & 99-01 CSAP scores ${ }^{d}$ & $\begin{array}{l}-1.365 \\
(.562)^{*}\end{array}$ & $\begin{array}{l}1.039 \\
(.821)\end{array}$ \\
\hline & $\begin{array}{l}\text { CSAP scores X } \\
\text { Poverty }\end{array}$ & $\begin{array}{r}-.002 \\
(.017)\end{array}$ & $\begin{array}{r}-.023 \\
(.020)\end{array}$ \\
\hline & $\begin{array}{l}\text { CSAP scores } X \\
\text { Minority }\end{array}$ & $\begin{array}{r}.029 \\
(.019)\end{array}$ & $\begin{array}{r}-.018 \\
(.024)\end{array}$ \\
\hline \multirow[t]{6}{*}{ Alternative opportunities and } & Salary difference & $\begin{array}{r}.054 \\
(.031)^{\dagger}\end{array}$ & $\begin{array}{r}.075 \\
(.031)^{*}\end{array}$ \\
\hline & $\begin{array}{l}\text { School leader } \\
\text { positions }\end{array}$ & $\begin{array}{r}-.001 \\
(.002)\end{array}$ & $\begin{array}{r}-.004 \\
(.004)\end{array}$ \\
\hline & North & $\begin{array}{r}.026 \\
(.571)\end{array}$ & $\begin{array}{l}-1.578 \\
(.833)^{\dagger}\end{array}$ \\
\hline & South & $\begin{array}{r}.227 \\
(1.006)\end{array}$ & $\begin{array}{r}-.537 \\
(1.346)\end{array}$ \\
\hline & West & $\begin{array}{r}-.396 \\
(.828)\end{array}$ & $\begin{array}{r}-.360 \\
(.876)\end{array}$ \\
\hline & Metro & $\begin{array}{r}-.463 \\
(.587)\end{array}$ & $\begin{array}{l}-.113 \\
(.806)\end{array}$ \\
\hline
\end{tabular}


Note: ${ }^{*} \mathrm{p}<.01^{*} \mathrm{p}<.05^{\dagger} \mathrm{p}<.10$

Dependent variable is whether or not the school leaders left their schools during 2000 and 2001 ( $1=$ yes, $0=$ no).

${ }^{a}$ Multiple logistic regression coefficients.

${ }^{\mathrm{b}}$ Standard error.

c The interaction term of poverty and minority was included because of the high correlation between these factors.

d The mean of standardized $4^{\text {th }}$ grade reading and writing scores in 1999, 2000, and 2001.

An indicator of working conditions, the dummy variable of large school was significantly associated with both female and male leaders' movements from their schools: They were more likely to leave large schools than middle-size schools. Contrary to past research findings on teacher movement (Hanuschek et al., 1999; 2001), the poverty level and the percentage of minority students were independent from school leaders' movement to other schools. School location and district expenditures on instruction and administration were also not significantly associated with school leader turnover.

In terms of alternative opportunities for the leaders, the salary difference between their new and old positions was significantly associated with transfers to other schools for male and female leaders: Those who had large increases in their salaries from 2000 to 2001 were more likely to move. For both female and male leaders, the number of school leader positions within their districts was not significantly associated with whether they left their schools to take other education-related positions. Colorado labor markets within the state were also independent from leader turnover, with one exception: Male leaders were less likely to move from the North region.

Finally, school achievement level, measured by the average standardized percentage of fourth-graders achieving at or above proficient level in reading and writing, was significantly associated with female leaders' transfers from their schools, while there was no significant relationship between school achievement level and male leaders' movements. Female leaders were more likely to leave low-achieving schools. One standard deviation increase, approximately 20 percent of students achieving at or above average indicates the decrease in the probability of school leaders leaving their schools by about 30 percent in the case of female leaders. Note 5 This achievement variable explains about 2 percent of the total variance for female leaders in the rates of attrition based on transferring schools. There was no significant interaction effect between achievement level and poverty and between achievement level 
and percentage of minority students.

This analysis revealed that school achievement level is an important predictor of the turnover of female leaders but not of male leaders. Although the size of the effect is moderate, this finding has significant policy implications for schools and districts that are considering effective retention strategies.

\section{Conclusion and Discussion}

This study represents the first systematic attempt to identify the predictors of school leaders' movement to other schools. Findings from this study can be summarized as follows.

- The retirement of the baby boomer generation is not the major factor contributing to the attrition rates of school leaders. Rather, moving to other schools, within or outside districts, accounts for a major part of school leader attrition.

- Attrition rates by gender and race indicate that female and minority leaders are more likely to leave their schools at age 35 or younger and at age 56 or older than male and non-minority leaders at the same ages.

- Both female and male leaders are more likely to move when there is an expected increase in compensation for transferring to another education-related position.

- Both female and male leaders are more likely to leave large schools than middle-size and small schools.

- School achievement level is significantly associated with female leaders' movements to other schools but not with male leaders' movements. Female leaders are more likely to leave low-achieving schools than high-achieving schools.

The analysis shows that more principals and assistant principals left their positions because they took other positions in education, rather than because they retired or found non-education-related positions. This indicates that if policy-makers address the reasons for leader attrition, there is a great possibility of lowering the attrition-unlike the situation of retiring school leaders, in which what policy-makers can do is quite limited. The majority of studies on school personnel attrition have focused on the people who left their education-related jobs elsewhere altogether, and little is known about what predicts the attrition explained by movement from one school to another. Therefore, it is important to understand the reasons why school leaders leave their schools to take other education-related jobs, in order to achieve an equal and effective distribution of school leaders among schools.

Attrition rates by gender and race indicate that female and minority leaders are more likely to leave their schools at age 35 or younger and at age 56 or older than male and non-minority leaders at the same ages. Higher attrition rates of female leaders compared to that of male leaders can be explained by maternity leave, the same reason for higher attrition rates of female teachers than male teachers in past studies. Orientation toward family of female leaders may also explain the early retirement reflected in their higher attrition rates. More studies are needed to understand why minority leaders are more likely to leave at a 
younger age and to retire early compared to non-minority leaders.

Male and female leaders are more likely to leave their schools when they expect a higher-paying position in education. Importance of salary increase as a factor contributing to school transfers has been explained in past studies on teacher turnover (Brewer, 1996; Murnane et al., 1988, 1989). At least one researcher has pointed out that male teachers are more sensitive to monetary incentives than female leaders (Brewer, 1996). The argument is supported by this study on leadership movement: The effect of salary difference was larger on male leaders than on female leaders. However, the significant level of salary difference effects for both male and female leaders may indicate that such gender difference effects may be smaller among school leaders than among teachers.

Large schools tend to lose school leaders more than middle-size and small schools do. It is difficult to discover the actual reason for these relationships; however, factors not examined in this study that are associated with large schools may be contributing to this relationship. For example, school leaders may prefer small schools because of their capacity to build close relationships with faculty and students. More studies are necessary in order to fully understand the association between school size and leaders' decisions to leave their schools.

We observed significant effects of school achievement on female leaders' movements, but school achievement was independent from male leaders' movements. The data indicate that female leaders are more likely to leave low-achieving schools. Two explanations are possible for the relationship between school achievement level and female leader movements. One is that female leaders decide to leave low-achieving schools because of the challenges they face in establishing leadership. Another is that they are replaced by other leaders by the district as a result of school restructuring or for school improvement. Our data do not allow us to identify which explanation is more plausible, although the first explanation is more likely given the uncommonness of whole schools being restructured.

In either case, it is likely that female leaders are facing more difficulties in low-achieving schools than male leaders. This may be explained by the gender disadvantage in establishing effective leadership within a male-dominated leader community. Organizational socialization research has revealed the nature of the socialization process that teaches a person the knowledge, values, and behaviors required of those filling a role within a particular organization (Monane, 1967). When a school as an organization expects conventional white male leadership, female and minority leaders struggle to lead because of the misalignment between their personal traits and the conventional leadership role expectations the school has. The stress female and minority leaders experience in enacting leadership due to lack of organizational support has been well-documented (Ortiz \& Marshall, 1988; Valverde, 1980)

Given such a disadvantage in establishing effective leadership, female leaders may try to avoid low-achieving schools, which pose additional challenges to female leaders. Under the accountability system, which demands improved 
student learning, the level of challenges female leaders face to be effective leaders in conventional organizational culture is especially enhanced.

Policy-makers and educators need to be aware of the gender disadvantages female leaders experience and should provide support to avoid having to lose capable female leaders.

While our results have significant policy implications based on the analyses of the statewide longitudinal data, our data possess limitations. First, this study utilized the data on elementary school principals and assistant principals only. Studies focusing on middle school or high school leaders may produce different results due to the differences in student population, school size, and organizational goals based on the students' developmental stages.

Second, our data is limited to one state. While our results may be reasonably applied to elementary schools in other states that are similar to Colorado, we need to be cautious about applying the results to states with different demographic and school system characteristics. Studies utilizing nationally representative data on the attrition of school leaders are needed.

Lastly, more information on the organizational environment of schools and on characteristics of school leaders is necessary, in order to understand the comprehensive picture of what predicts school leaders' movements from one school to another. The quality of school leaders-such as their levels of interest in and orientation toward professional development, advancement, and promotion; the nature of their educational visions and goals; and the degree to which they support standardized testing systems would be important factors needing to be examined. In addition, information such as the nature of a school's decision-making system (i.e., the level of teacher involvement in decision-making); the level of shared values among teachers; the level of teacher professionalism in subject matter, in the case of middle schools; and agreement with and support for standardized testing systems would significantly enhance the data capacity to examine what working conditions predict school leaders' movements.

Despite these limitations, the findings from this study provide important policy-relevant information. The fact that the major part of attrition rates are explained by movement rather than retirement indicate that policy-makers and practitioners need to pay attention to principals' and assistant principals' movements to other schools in addition to retirement when designing and implementing policies to solve their high attrition rates. We need to be also aware that because female and minority leaders are more likely to leave at age 35 or younger and at age 56 or older, they should be provided enough support to overcome any possible challenges they are experiencing when they decide to leave their schools.

The data suggest that limited monetary compensation is a crucial factor that needs improvement in order to keep qualified elementary school principals and assistant principals. Policy-makers should also understand the gender differences in the predictors of leadership turnover. Schools and districts need to provide support for school leaders, especially female leaders, to use their leadership effectively so that student achievement can improve and that the challenges in low-achieving schools can be overcome. 


\section{Notes}

This study was conducted while the authors were at Mid-Continent Research for Education and Learning (McREL). We would like to thank Dr. Zoe Barley, Dr. Helen Apthorp, and Dr. Kerry Englert for their valuable comments on the earlier manuscript and support of this study.

1. The data on elementary schools only were selected because the data included the largest number of schools and leaders compared to middle schools and high schools, allowing us to have enough statistical power in the analysis. We defined K-5 and K-6 schools as elementary schools.

2. The data did not allow us to separate principals and assistant principals. Therefore, we chose the population of principals and assistant principals and defined them as school leaders.

3. Schools were assigned to one of three different locales-urban, suburban, or rural-using locale codes contained in the 2000-01 National Center for Education Statistics (NCES) Common Core of Data (CCD) for schools. In this study, the six locale codes in the CCD were combined into three more general locales: urban, suburban, and rural. Schools classified as urban had NCES-assigned locales of large central city or mid-size central city. Schools classified as suburban had NCES-assigned locales for urban fringe to large city or mid-size city. Schools were classified as rural if they had NCES-assigned locales for large town, small town, or rural.

4. All the percentages on achievement used in this study were standardized based on the equation (school percentage at and above proficient) (state mean percentage at and above proficient) / (the standard deviation of the school percentage within the state). This was done in order to standardize the percentage across different subject levels and grade levels.

5. A logit estimation procedure was used to interpret the logistic regression coefficients based on the following equation:

$P=\exp \left(L_{1}\right) /\left[1+\exp \left(L_{1}\right)\right]-\exp \left(L_{0}\right) /\left[1+\exp \left(L_{0}\right)\right]$

where $P$ is the increase in the probability of the school leaders leaving their schools when $X$ increases one unit. $L_{0}$ is the logit before the unit change in $X$, and $L_{1}$ is the logit after the unit change in $X$.

\section{References}

Adams, J. P. (1999). Good Principals, Good Schools. Thrust for Educational Leadership, 29(1), 8-11.

Andrews, R. L., \& Soder, R. (1987). Principal Leadership and Student Achievement. Educational Leadership, 44(6), 9-11.

Baugh, W. H., \& Stone, J. A. (1982). Mobility and Wage Equilibrium in the Educator Labor Market. Economic of Education Review, 2(3), 253-274.

Bobbitt, S., Leich, M., \& Cook, L. (1997). Whither didst thou go. journal of special education, 30, 371-389.

Bobbitt, S., Leich, M., Whitener, S., \& Synch, H. (1994). Characteristics of stayers, movers, and leavers: Results from the teacher follow up survey, 1991-1992. Washington, DC: National Center for Educational Statistics. 
Boe, E., Bobbitt, S., Cook, L., Barkenic, G., \& Maislin, G. (1998). Teacher Turnover in eight cognate areas: National trends and predictors. Philadelphia, PA: University of Pennsylvania, Center for Research and Evaluation in Social Policy.

Brewer, D. J. (1996). Career Paths and Quit Decisions: Evidence from Teaching. Journal of Labor Economics, 14(2), 313-339.

Carroll, S., Reichardt, R., \& Guarino, C. (2000). The Distribution of Teachers among California's School Districts and Schools. Santa Monica, CA: RAND Corporation.

Chapman, D., \& Hutcheson, S. (1982). Attrition from teaching careers: A discriminant analysis. The American Education Research Journal, 19, 93-105.

Cooley, V. E., \& Shen, J. (2000). Factors Influencing Applying for Urban Principalship. Education and Urban Society, 32(4, Aug), 443-454.

Copland, M. A. (2001). The myth of the superprincipal. Phi Delta Kappan, 82(7, March), 528-533.

Cunningham, W. G., \& Burdick, G. R. (1999). Empty Offices. American-School Board Journal, December, 25-30.

Darling-Hammond, L., \& Green, J. (1994). Teacher quality and equality. In P. Keating \& J. I. Goodlad (Eds.), Access to Knowledge. New York: College Entrance Examination Board.

Eberts, R. W. (1987). Union-Negotiated Employment Rules and Teacher Quits. Economics of Education Review, 6(1), 15-25.

Ehrenberg, R. G., Chaykowski, R. P., \& Ehrenberg, R. A. (1988). Determinants of the Compensation and Mobility of School Superintendents. Industrial and Labor Relations Review, 41(3), 386-401.

Greenberg, D. H., \& McCall, J. J. (1974). Teacher mobility and allocation. journal of human resources, 9(4), 480-502.

Grissmer, D. W., \& Kirby, S. N. (1987). Teacher attrition: The uphill climb to staff the nation's schools. Santa Monica, CA: Rand Corporation.

Grissmer, D. W., \& Kirby, S. N. (1992). Patterns of attrition among Indiana teachers, 1965-1987. Santa Monica, CA: Rand Corporation.

Grissmer, D. W., \& Kirby, S. N. (1997). Teacher turnover and Teacher quality. teachers college record, 99(1), 45-56.

Hafner, A., \& Owings, J. (1991). Careers in teaching: following members of the high school class of 1972 in and out of teaching (NCES Report No. 91-470). Washington, DC: U.S. Department of Education, National Center for Education Statistics.

Haggstrom, G. W., Darling-Hammond, L., \& Grissmer, D. W. (1988). Assessing teacher supply and demand. Santa Monica, CA: Rand Corporation.

Hanuschek, E. A., Kain, J. F., \& Rivkin, S. G. (1999). Do higher salaries buy better teachers? Paper presented at the Annual meetings of the American Economic Association, New York.

Hanushek, E. A., Kain, J. F., \& Rivkin, S. G. (2001). Why Public Schools Lose Teachers. Cambridge, MA: National Bureau of Economic Research.

Heyns, B. (1988). Educational defectors: a first look at teacher attrition in the NLS-72. Educational Researcher, 17, 24-32.

Ingersoll, R. M. (2001). Teacher Turnover, Teacher Shortages, and the Organization of Schools: Center for the Study of Teaching and Policy.

Kozol, J. (1991). Savage inequalities. New York: Harper-Collins.

Leithwood, K. A., \& Montgomery, D. J. (1982). The role of the elementary school principal in program improvement. Review of Educational Research, 52, 309-339. 
Miech, R., \& Elder, R. (1996). The service ethic and teaching. Sociology of Education, 69, 237-253.

Monane, J. H. (1967). A sociology of human systems. New York: Appleton, Century, Crofts.

Mont, D., \& Rees, D. (1996). The influence of classroom characteristics on high school teacher turnover. Economic Inquiry, 34, 152-167.

Murnane, R. J. (1981). Teacher mobility revisited. Journal of Human Resources, 16(1), 3-19.

Murnane, R. J. (1987). Understanding teacher attrition. Harvard Educational Review, 57(2), 177-182.

Murnane, R. J., \& Olsen, R. J. (1989). The Effects of Salaries and Opportunity Costs on the Length of Stay in Teaching: Evidence from Michigan. Review of Economics and Statistics, 71(2), 347-352.

Murnane, R. J., \& Olsen, R. J. (1990). The Effects of Salaries and Opportunities Costs on the Length of Stay in Teaching. journal of human resources, 25(1), 106-124.

Murnane, R. J., Singer, J. D., \& Willett, J. B. (1988). The career paths of teachers: implications for teacher supply and methodological lessons for research. Educational Researcher, 17(5), 22-30.

Murnane, R. J., Singer, J. D., \& Willett, J. B. (1989). The influences of salaries and "opportunity costs" on teachers' career choices: evidence from north carolina. Harvard Educational Review, 59(3), 325-346.

Murnane, R. J., Singer, J. D., Willett, J. B., Kemple, J., \& Olsen, R. (1991). Who will teach?: Policies that matter. (Vol. Harvard University Press).

National_Association_of_Elementary_School_Principal s. (1998). Is there a shortage of qualified candidates for opening in the principalship? An exploratory study. Alexandria, VA: Author.

Ortiz, F. I., \& Marshall, C. (1988). Women in educational administration. In N. J. Boyan (Ed.), Handbook of research on educational administration (pp. 123-142). New York: Longman.

Papa, F. C., Lankford, H., \& Wyckoff, J. (2002). The Attributes and Career Paths of Principals: Implications for Improving Policy. Albany: University at Albany, SUNY.

Rees, D. (1991). Grievance Procedure Strength and Teacher Quits. Industrial and Labor Relations Review, 45(1), 31-43.

Rollefson, M., \& Broughman, S. (1995). Teacher supply in the United States: Sources of newly hired teachers in public and private schools, 1988-1991. Washington, DC: National Center for Education Statistics.

Rumberger, R. (1987). The impact of salary differentials on teacher shortages and turnover: The case of mathematics and science teachers. Economics of education review, 6, 389-399.

Schlecty, P., \& Vance, V. (1981). Do academically able teachers leave education? The North Carolina Case. Phi Delta Kappan, 63, 105-112.

Schlecty, P., \& Vance, V. (1983). Recruitment, selection and retention: The shape of the teaching force. Elementary School Journal, 83, 469-487.

Theobald, N. D. (1990). An Examination of the Influence of Personal, Professional, and School District Characteristics on Public School Teacher Retention. Economics of Education Review, 9(3), 241-250.

Theobald, N. D., \& Gritz, R. M. (1996). The Effects of School District Spending Priorities on the Exit Paths of Beginning Teachers Leaving the District. Economics of Education Review, 15(1), 11-22.

U.S. Bureau of Labor Statistics. (2002). Occupational Outlook Handbook 2002-2003 (Vol. 2002).

Useem, E., Christman, J. B., Gold, E., \& Simon, E. (1996). Reforming Alone: Barriers to Organizational Learning in Urban School Change Initiatives. Paper presented at the American Educational Research Association, New York City. 
Valverde, L. A. (1980). Promotion socialization: the informal process in large urban districts and its adverse effects on non-white and women. Journal of Educational Equity and Leadership, 1, 36-46.

Zigarelli, M. A. (1996). An empirical test of conclusions from effective schools research. The journal of educational research, 92(2), 103-110.

\section{About the Authors}

\section{Motoko Akiba}

Research Assistant Professor

202 Hill Hall

University of Missouri-Columbia

Phone: (573) 884-3730

Fax: (573) 885-5714

Email: akibam@missouri.edu

Motoko Akiba is a research assistant professor of Educational Policy in the department of Educational Leadership and Policy Analysis at the University of Missouri-Columbia. Dr. Akiba's research program focuses on the identification of effective school conditions that improve learning and health-related behaviors of $\mathrm{K}-12$ students from high-poverty communities.

Robert Reichardt, PhD

Executive Director, Alliance for Quality Teaching

1410 Grant St. Suite 105-B

Denver, CO 80203

Phone: $303-839-8400$

Fax: 303-861-1501

robert@qualityteaching.org

www.qualityteaching.org

Robert Reichardt is Executive Director of the Alliance for Quality Teaching, a non-profit organization that works to improve teacher quality in Colorado through research, networking, and advocacy. Prior to working at the Alliance , Robert was a Senior Researcher at Mid-Continent Research for Education and Learning.

The World Wide Web address for the Education Policy Analysis Archives is epaa.asu.edu

\section{Editor: Gene V Glass, Arizona State University}

\section{Production Assistant: Chris Murrell, Arizona State University}

General questions about appropriateness of topics or particular articles may be addressed to the Editor, Gene V Glass, glass@asu.edu or reach him at College of Education, Arizona State University, Tempe, AZ 85287-2411. The Commentary Editor is Casey D. Cobb:

casey.cobb@unh.edu. 


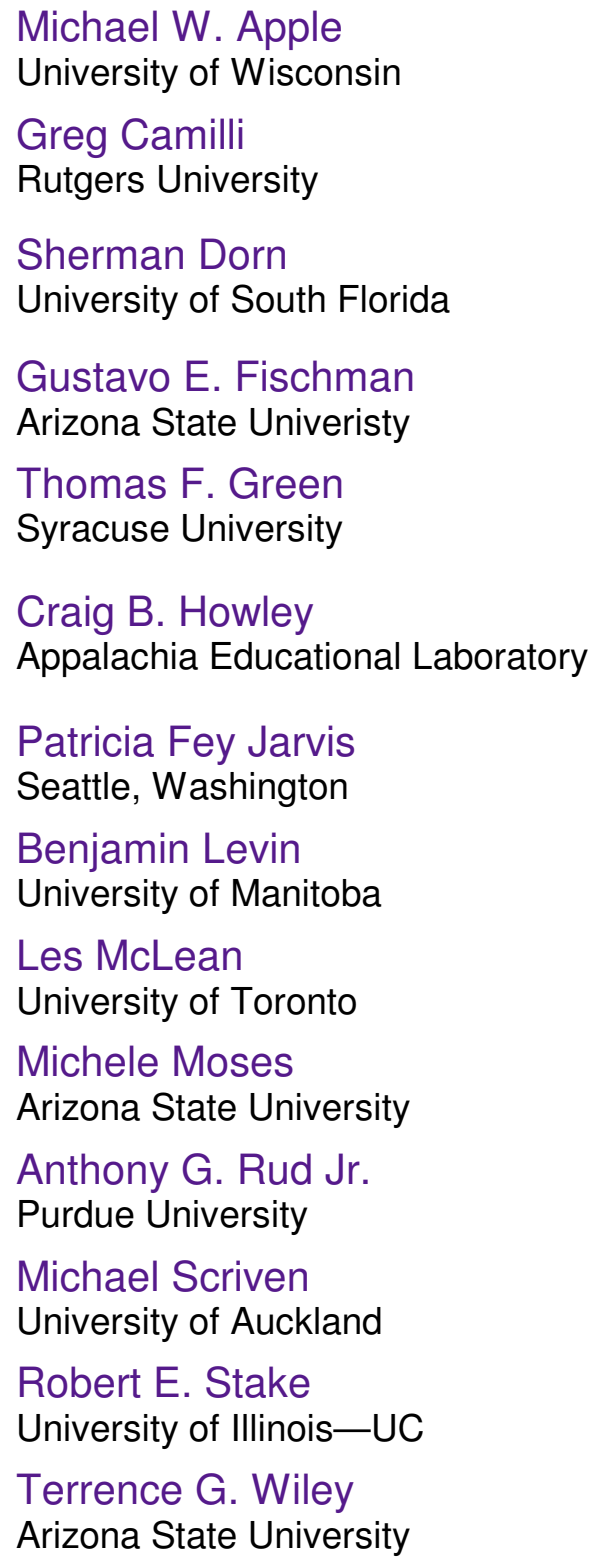

\author{
David C. Berliner \\ Arizona State University \\ Linda Darling-Hammond \\ Stanford University \\ Mark E. Fetler \\ California Commission on Teacher \\ Credentialing \\ Richard Garlikov \\ Birmingham, Alabama \\ Aimee Howley \\ Ohio University \\ William Hunter \\ University of Ontario Institute of \\ Technology \\ Daniel Kallós \\ Umeå University \\ Thomas Mauhs-Pugh \\ Green Mountain College \\ Heinrich Mintrop \\ University of California, Los Angeles \\ Gary Orfield \\ Harvard University \\ Jay Paredes Scribner \\ University of Missouri \\ Lorrie A. Shepard \\ University of Colorado, Boulder \\ Kevin Welner \\ University of Colorado, Boulder \\ John Willinsky \\ University of British Columbia
}

\title{
EPAA Spanish and Portuguese Language Editorial Board
}

\author{
Associate Editors for Spanish \& Portuguese \\ Gustavo E. Fischman \\ Arizona State University \\ fischman@asu.edu \\ Pablo Gentili \\ Laboratório de Políticas Públicas \\ Universidade do Estado do Rio de Janeiro
}




\section{Founding Associate Editor for Spanish Language (1998-2003) Roberto Rodríguez Gómez Universidad Nacional Autónoma de México}

\author{
Adrián Acosta (México) \\ Universidad de Guadalajara \\ adrianacosta@compuserve.com \\ Teresa Bracho (México) \\ Centro de Investigación y Docencia \\ Económica-CIDE \\ bracho dis1.cide. $\mathrm{mx}$ \\ Ursula Casanova (U.S.A.) \\ Arizona State University \\ casanova@asu.edu \\ Erwin Epstein (U.S.A.) \\ Loyola University of Chicago \\ Eepstein@luc.edu \\ Rollin Kent (México) \\ Universidad Autónoma de Puebla \\ rkent@puebla.megared.net.mx \\ Javier Mendoza Rojas (México) \\ Universidad Nacional Autónoma de \\ México \\ javiermr@servidor.unam.mx \\ Humberto Muñoz García (México) \\ Universidad Nacional Autónoma de \\ México \\ humberto@servidor.unam.mx \\ Daniel \\ Schugurensky(Argentina-Canadá) \\ OISE/UT, Canada \\ dschugurensky@oise.utoronto.ca \\ Jurjo Torres Santomé (Spain) \\ Universidad de A Coruña \\ jurjo@udc.es
}

\author{
J. Félix Angulo Rasco (Spain) \\ Universidad de Cádiz \\ felix.angulo@uca.es \\ Alejandro Canales (México) \\ Universidad Nacional Autónoma de \\ México \\ canalesa@servidor.unam.mx \\ José Contreras Domingo \\ Universitat de Barcelona \\ Jose.Contreras@doe.d5.ub.es \\ Josué González (U.S.A.) \\ Arizona State University \\ josue@asu.edu \\ María Beatriz Luce(Brazil) \\ Universidad Federal de Rio Grande do \\ Sul-UFRGS \\ lucemb@orion.ufrgs.br \\ Marcela Mollis (Argentina) \\ Universidad de Buenos Aires \\ mmollis@filo.uba.ar \\ Angel Ignacio Pérez Gómez (Spain) \\ Universidad de Málaga \\ aiperez@uma.es \\ Simon Schwartzman (Brazil) \\ American Institutes for \\ Resesarch-Brazil (AIRBrasil) \\ simon@sman.com.br \\ Carlos Alberto Torres (U.S.A.) \\ University of California, Los Angeles \\ torres@gseisucla.edu
}

